
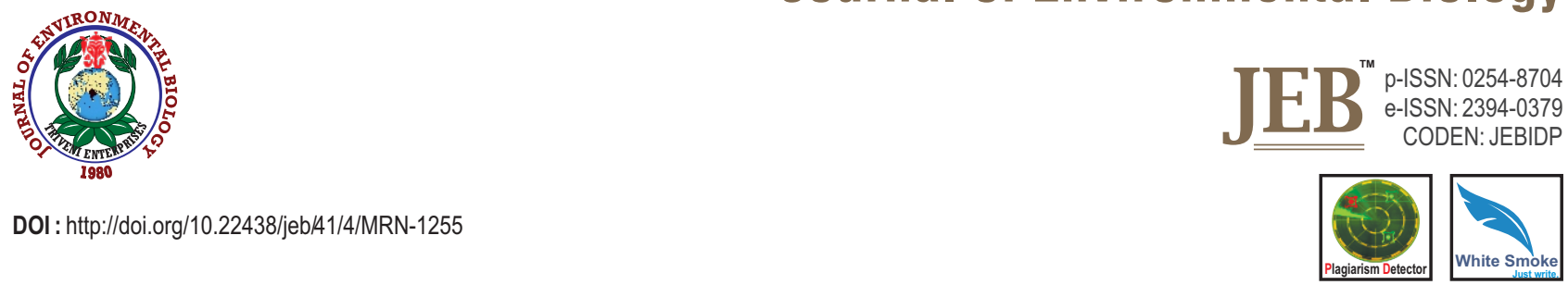

\title{
Evaluation of hybrids and single spore isolates of paddy straw mushroom Volvariella volvacea (Bull.) Singer for fruiting body yield and nutritional quality
}

\author{
O.P. Ahlawat* and H. Kaur \\ ICAR-Directorate of Mushroom Research, Solan-173 213, India \\ *Corresponding Author Email : ahlawat22op@gmail.com
}

\begin{abstract}
Aim: Developing high yielding single spore isolates and hybrid strains of paddy straw mushroom (Volvariella volvacea) with superior nutritional composition of the fruiting bodies.
\end{abstract}

Methodology: Two contrasting high yielding strains (DMRO-463 and DMRO-484) of V. volvacea previously released for higher fruiting body yield were used for isolation of single spore isolates (SSIs). The slow growing SSIs were used for developing the hybrid strains by mating on Malt Extract Agar Medium Petri dishes. Conversely, the fast growing SSIs and the developed hybrid strains were screened for downward mycelial growth on paddy straw filled in wide mouth test tubes. Based upon downward mycelial growth, only eight SSIs and ten hybrid strains with numerically higher downward mycelial growth compared to two parents' checks were further evaluated for fruiting body yield on composted cotton ginning mill waste substrate under indoor conditions.

Results: In successive yield evaluation trials (one preliminary and three full scale), hybrid strains $\mathrm{VvH}-11, \mathrm{VvH}-13$ and $\mathrm{VvH}-18$ gave fruiting body yield higher than the two parents. Out of these hybrids, the yield distribution at different height (selves) in growing room was consistent in hybrid $\mathrm{VvH}$ 13 in trial-2, while rest two hybrids and parents showed significantly lower yield in lowest self ( $30 \mathrm{~cm}$ above floor level). The fruiting body weight also showed similar trend. The fruiting bodies from the highest yielding hybrid $\mathrm{VvH}-11$ exhibited highest level of crude fiber $(2.07 \%)$ and ash $(10.95 \%)$ contents, while the hybrid $\mathrm{VvH}-13$ giving consistent yield across growing room exhibited higher level of crude fiber $(2.00 \%)$, vitamin C $(52.35 \mathrm{mg}$ $\left.100 \mathrm{~g}^{-1}\right)$ and vitamin D $\left(1434.7 \mu \mathrm{g} 100 \mathrm{~g}^{-1}\right)$. The third hybrid $\mathrm{VvH}-18$ was superior in crude fiber (1.74\%), manganese (22.46 ppm), selenium (0.26

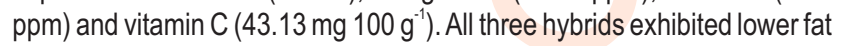
( 1.54 to $1.86 \%$ ) content compared to parents (2.54 to $2.59 \%$ ).

Interpretation: High yielding hybrid strains can be developed in paddy straw mushroom ( $V$. volvacea) through mating of slow growing SSIs, and their screening involving downward mycelial growth on paddy straw and repetitive grow out trials.

Keywords: Downward mycelial growth, Fruiting body, Single spore isolate, Volvariella volvacea

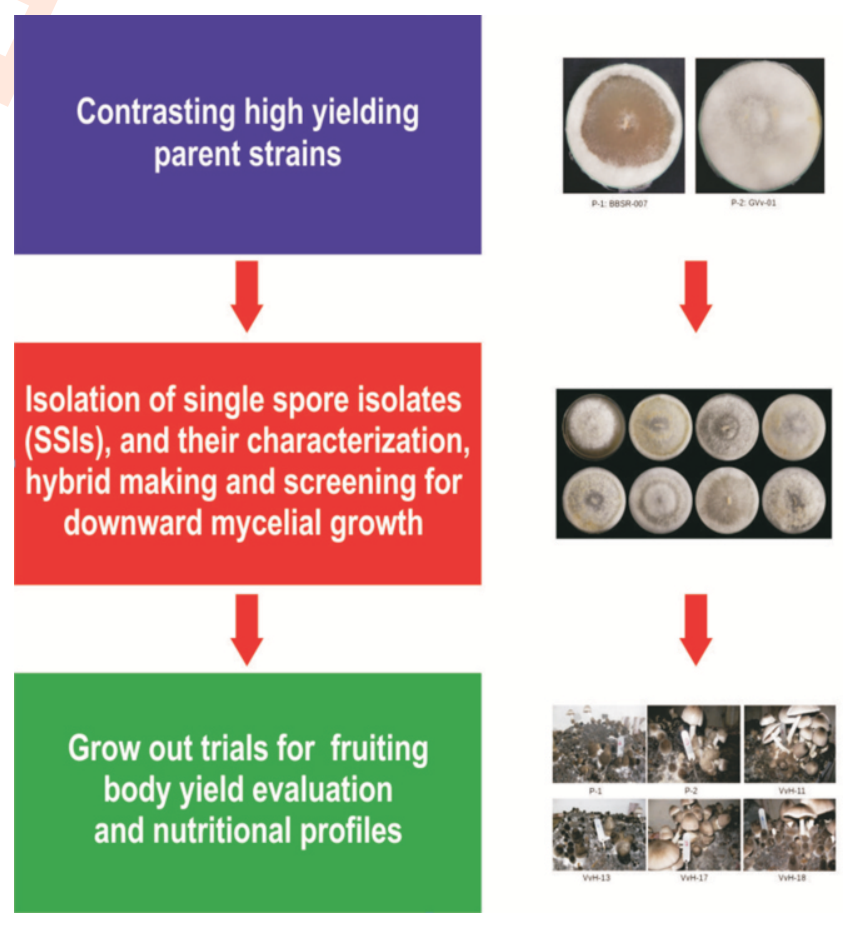

How to cite : Ahlawat, O.P. and H. Kaur: Evaluation of hybrids and single spore isolates of paddy straw mushroom Volvariella volvacea (Bull.) Singer for fruiting body yield and nutritional quality. J. Environ. Biol., 41, 727-734 (2020). 


\section{Introduction}

Volvariella volvacea (Bull.) Singer also known as paddy straw mushroom, is mainly grown under natural conditions between temperature of $28-35^{\circ} \mathrm{C}$ using fresh or partially fermented substrate (Chang, 1978). It is the fastest growing mushroom among all edible mushrooms and its cropping period varies from 20 to 30 days depending upon the substrate and environmental conditions used for cropping (Ahlawat et al., 2009). This mushroom accounts $5 \%$ of the total world mushroom production and placed jointly at $5^{\text {th }}$ position along with Flammulina velutipes (Bao et al., 2013). China is the main producer of this mushroom and more than $80 \%$ of the world production comes from Chinese mainland (Bao et al., 2013). In India, Odisha state alone produces approximately 10,000 tonnes of this mushroom (Thakur, 2014). Other states like Chhattisgarh, Jharkhand, West Bengal, Andhra Pradesh and Karnataka are also actively involved in its production. Along with pleasant aroma, delicate texture, easy to cook and simple cultivation technology, this mushroom is also known for its pharmacological properties like anti-tumor polysaccharides, immunosuppressive proteins, and immunomodulatory lectins (She et al., 1998). Despite of having plenty of favourable attributes, the inconsistent and low fruiting body yield has hampered its spread to new niches of the world.

The fruiting body yield in mushrooms is determined mainly by yielding potential of mushroom strain, cultural practices practiced and the climatic conditions maintained during cropping cycle (Ahlawat et al., 2011). The last two factors are in the hand of the mushroom entrepreneurs, while the first one is mainly managed by technically qualified scientists or the technical personnel. Although there are several firms involved in mushroom strains development programmes, however, most of them are not touching this mushroom considering it as the mushroom of only South-East Asian countries. Another reason might be the lesser understood life cycle and till recent it was considered as primary homothallic specie (Chiu, 1993), where all the single spore isolates are capable of forming fruiting body without involvement of the opposite mating type strains. However, the recent research findings have contradicted this notion and presented it as the secondary homothallic mushroom just like that of $A$. bisporus (Bao et al., 2013; Xiong et al., 2014), where developing hybrid strains is possible using conventional techniques. The researchers around the world have attempted strain development in this mushroom, either by selection of the promising strain (Garcha et al., 1986) or by using mating type genes in molecular marker assisted breeding (Xiong et al., 2014), protoplast fusion between diverse species (He et al., 2018) and hybridization using slow growing SSls (Ahlawat et al., 2017). Considering conventional breeding as the simple and effective tool, the present study thus, aimed at generating hybrid strains by making crosses between slow growing compatible SSIs for higher fruiting body yield and nutritional quality.

\section{Materials and Methods}

Isolation of single spore isolates, hybrid strains development and their screening: Three strains of $\mathrm{V}$. volvacea viz., DMRO-463 (BBSR-007), DMRO-484 (GVv-01) and DMRO247 (OE-274) with contrasting characteristics for mycelial growth as well as fruiting bodies were collected from ICAR-Directorate of Mushroom Research (DMR) Culture Collection and Gene Bank, Solan, India. The strains were first grown on paddy straw substrate, and healthy, young fruiting bodies were used for isolation of single spore isolates (SSIs) on Malt Extract Agar (MEA) medium, following standard protocol (Chang et al., 1981). The SSIs were divided into two types; (a) fast growing with 'typical' mycelial growth characteristics and (b) slow growing with 'atypical' mycelial growth characteristics as per the guidelines of Chang et al. (1981). The 54 fast growing SSls with 'typical' mycelial growth characteristics of $V$. volvacea were further studied for their downward mycelial growth on sterilized paddy straw filled in wide mouth glass test tubes $(38 \mathrm{~mm} \times 200 \mathrm{~mm}$, dia. $x$ I) in triplicate as per the method of Mehta (1988). Nine SSIs of parent strain DMRO-247, 19 of strain DMRO-463 and 26 of strain DMRO-484 were used in the study. The SSIs were coded keeping in consideration the parent strains and the serial number allotted. Eight out of 54 SSIs, exhibiting numerically higher downward mycelial growth compared to parent strains were selected for initial fruiting body yield evaluation on composted cotton ginning mill waste with $10 \mathrm{~kg}$ compost/bed and seven beds/SSI.

A total of 132 hybrids were developed by using 12 slow growing SSIs $(204,209,217,226,237,248,261,292,295,308$, 329 and 358) of parent strain DMRO-463 and 11 SSIs (211, 247, $259,264,273,289,297,303,312,319$ and 321) of parent strain DMRO-484 by co-growing on Malt Extract Agar Petri dishes and picking the mycelial bit from the confrontation zone of the two SSIs. The developed hybrids, SSIs and the parent strains were further screened for their downward mycelial growth on sterilized pounded paddy straw in wide mouth tubes by the method of Mehta (1988). Ten hybrids showing numerically higher downward mycelial growth compared to parent strains were further used for initial fruiting body yield valuation along with two parent strains on composted cotton ginning mill waste with $10 \mathrm{~kg}$ compost/bed and seven beds/hybrid, SSI and parent strains.

Evaluation trial: One preliminary and three large scale evaluation trials were conducted at environment controlled mushroom cultivation facility, ICAR-DMR, Solan, India. The evaluation trials were conducted using the composted cotton ginning mill waste substrate and the paddy straw based spawn as per the protocols of Quimio (1993) and Chang and Miles (2004) improvised by Ahlawat et. al. (2009). Spawning was done @ 1.5\% of the composted substrate on selves followed by complete covering of substrate with transparent plastic sheets. The temperature inside the substrate beds was kept at $34 \pm 2{ }^{\circ} \mathrm{C}$ and $30 \pm 2{ }^{\circ} \mathrm{C}$ during mycelial colonization of the substrate and fruiting, 
respectively. The relative humidity ranged between 85 to $90 \%$ during both the stages (mycelial colonization and fruiting). Fluorescent light of 500-600 lux day ${ }^{-1}$ was given from $5^{\text {th }}$ days post-spawning until crop termination. After initial screening of ten hybrid strains (BBSR-007-F + GVv-01-V, BBSR-007-E + GVv-01T, BBSR-007-17 + GVV-01-37, BBSR-007-E + GVV-01-Y, BBSR007-F + GVv-01-Z, BBSR-007-17 + GVv-01-34, BBSR-007-28 + GVv-01-37, BBSR-007-D + GVV-01-T, BBSR-007-A + GVv-01-Z and BBSR-007-C + GVV-01-T) and eight SSIs (VV-13-2-23, VV13-2-28, BBSR-007-02, BBSR-007-17, BBSR-007-22, GVv-01101, GVv-01-106 and GVv-01-108) for fruiting body yield potential with two parents as checks (Table 1), two SSIs and five hybrid strains were taken to the next level of screening. The hybrid strains and SSIs selected for large scale yield evaluation trials were VvH-11 (BBSR-007-F + GVv-01-V), VvH-13 (BBSR-007-E + GVv-01-T), VvH-16 (BBSR-007-17 + GVv-01-37), VvH-17 (BBSR-007-E + GVv-01-Y), VvH-18 (BBSR-007-F + GVv-01-Z), VvS-11 (Vv-13-2-23) and VvS-16 (GVv-01-101). The parent strains used were P-1 (DMRO-463) and P-2 (DMRO-484).

The initial screening trial was conducted in July-August 2016, while the subsequent large-scale yield evaluation trial 1, 2 and 3 were conducted during October-November 2016, April-May 2017 and June-July 2017, respectively. The process of indoor composting was performed in two phases involving 4 days outdoor composting and 4 days indoor composting (pasteurization at $60 \pm 2^{\circ} \mathrm{C}$ for $6-8 \mathrm{hrs}$ and conditioning at $50 \pm 2$ ${ }^{\circ} \mathrm{C}$ for $\left.36-48 \mathrm{hrs}\right)$. The large-scale evaluation trials were conducted by using $20 \mathrm{~kg}$ compost bed ${ }^{-1}$ with 6 to 12 replications strain $^{-1}$ in different trials. The master spawn was prepared on wheat grains while ready to use spawn on chopped paddy straw as per the methodology of Chang and Miles (2004) improvised by Ahlawat et al. (2009). All the evaluation trials were conducted in Randomized Block Design (RBD). The cropping conditions and data recording for different yield related attributes like time taken for first harvest (days post-spawning), mushroom (fruiting body) yield ( $\mathrm{kg} 100 \mathrm{~kg}^{-1}$ dry substrate) and mean fruit body weight (g) were done as per the method of Ahlawat et al. (2011). The fruiting body yield data was recorded for two flushes spread for 20-25 days post-spawning in different strains. The fruit bodies were harvested ategg stage.

Nutritional analysis of mushroom fruit bodies: The randomly harvested 15 fruiting bodies from promising hybrid strains, SSIs and parent strains were analyzed for ten different parameters viz., protein, fat, crude fiber, ash, vitamin-C, vitamin-D and four different minerals (potassium, manganese, zinc and selenium) on dry weight basis. Protein, crude fiber, fat and ash content were determined by standard protocols of AOAC (AOAC, 2002). The protein was determined first by determination of nitrogen percentage using Micro-Kjeldahl method, followed by multiplication of $\mathrm{N} \%$ with a factor of 6.25 . Mineral constituents (zinc, selenium and manganese) were determined with ICP-MS method 999.10 (AOAC, 2002), while potassium by flame photometer. Vitamin $D$ as ergocalciferol or Vitamin $D_{2}$ was determined using High Performance Liquid Chromatography (HPLC) as per the AOAC method 2011.11 further standardized at PBTI, Mohali, India (AOAC, 2012). It was determined at a wavelength of $266 \mathrm{~mm}$ by using Eclipse XCB-C18 column, DAD (UV-VIS) detector and Methanol/Acetonitrile/Water as the mobile phase. From $10 \mathrm{~g}$ mushroom sample, saponified extract was prepared and out of it $1 / 10^{\text {th }}$ extract was loaded on silica gel column, followed by elution with n-heptane, drying and reconstitution using $\mathrm{n}$-hexane/isopropanol. The reconstituted sample was run on HPLC along with requisite standard. Vitamin C was analyzed as per the AOAC Method 967.21 (AOAC, 2007), first by taking five grams of the pounded mushroom sample in 100 $\mathrm{ml}$ graduated flask along with $5 \%$ metaphosphoric acid. It was shaken and the final volume was made up to $100 \mathrm{ml}$ with metaphosphoric acid and filtered immediately through a filter paper. $\mathrm{A} 10 \mathrm{ml}$ of the filtrate was titrated against standard solution of indophenol solution. Vitamin C content in the sample was calculated by the equation given below:

$$
\text { Vitamin C (mg } \left.100 \mathrm{~g}^{-1} \text { of sample }\right)=A \times B \times 1000 / \mathrm{W}
$$

where, $A=$ volume (in $\mathrm{ml}$ ) of the indophenol solution used for titration, $B$ = weight (in $\mathrm{mg}$ ) of the ascorbic acid equivalent to one milliliter of indophenol solution and W= weight (in g) of the sample taken for the test.

Statistical analyses: Statistical Tool for Agricultural Research (STAR), Version: 2.0.1 of International Rice Research Institute (IRRI), Philippines was used for statistical analysis of the data using single factorial ANOVA (http://bbi..jri.org) (STAR, 2014). Comparison of means was carried out using Tukey test of significance (Tukey, 1949).

\section{Results and Discussion}

The fast growing SSIs with 'typical' mycelial growth characteristics of $V$. volvacea, showed quite high variation in their mycelial growth characteristics on MEA and downward mycelial growth on pounded paddy straw. After seven days of incubation, eight SSIs (listed in materials and methods) out of 54 showed numerically higher downward mycelial growth compared to parent strains (without going for statistical analysis) were taken for initial fruiting body yield evaluation trial. Similarly, out of 132 hybrid strains (presumed to be hybrid strains based upon the confrontation zones formed between two co-grown slow growing SSIs), 10 hybrid strains (listed in materials and methods) were selected for the initial fruiting body yield evaluation trial. Except for one report each in Agaricus bisporus (Mehta, 1988) and V. volvacea (Ahlawat et al., 2017); this approach has not been used for selecting the high yielding strains in mushrooms. It can be ascertained to the efficient assimilation and utilization of nutrients from natural substrates by the faster downward growing SSIs/hybrid strains and their conversion into fruiting bodies. 
Out of eight selected fast growing SSIs (VvS-11 to VvS18) and ten hybrid strains, five hybrid strains $(\mathrm{VvH}-11, \mathrm{VvH}-13$, $\mathrm{VvH}-16, \mathrm{VvH}-17$ and $\mathrm{VvH}-18$ ) exhibited significantly higher fruiting body yield compared to parent strains based upon Tukey test of significance. Highest yield was recorded in hybrid strain $\mathrm{V} v \mathrm{H}-16$, followed by $\mathrm{VvH}-17, \mathrm{VvH}-11, \mathrm{VvH}-18$ and $\mathrm{VvH}-13$. Fruiting body weight $(\mathrm{g})$ was also highest $(27.73 \mathrm{~g})$ in hybrid strain $\mathrm{VvH}-16$, followed by hybrid strain $\mathrm{VvH}-18(26.35 \mathrm{~g})$ and $\mathrm{VvH}-11$ (23.96 g), as compared with parent strains P-1 (16.68 g) and P-2 $(22.14 \mathrm{~g})$ (Table 1). Time taken for first harvest was statistically at par in hybrid strains, SSls and parent strains, and ranged between 11.82 to 13.34 days. Use of initial evaluation trial with large number of strains or SSIs and smaller size substrate beds is a routine practice in mushrooms for taking up the strains to the next level of yield evaluation (Ahlawat et al., 2011; 2017). It is helpful in screening large number of strains in one go along with saving of substrate, time and labour.

Three consecutive yield evaluation trials conducted during different seasons revealed different yielding patterns in different SSIs and hybrid strains. In trial-1, hybrid strain $\mathrm{VvH}-18$ gave significantly higher fruiting body yield compared to two parents. In hybrid strains, VvH-11, VvH-13 and SSI VvS-11, the fruiting body yield was only numerically higher than the parent strains. In trial-2, the yield was statistically at par in hybrid strains $\mathrm{V} v \mathrm{H}-11, \mathrm{VvH}-13, \mathrm{~V} v \mathrm{H}-18$ and SSI VvS-11, compared to two parents. However, in trial-3, it was significantly high in hybrid strain $\mathrm{VvH}-11$ and $\mathrm{VvH}-13$. The cumulative mean fruiting body yield of three trials, hybrid strain $\mathrm{VvH}-11, \mathrm{VvH}-13$ and $\mathrm{VvH}-18$ to be superior yielder compared to the parent strains (Table 2). The mean fruiting body weight was significantly high in hybrid strain $\mathrm{VvH}-18(21.05,20.11$ and $19.99 \mathrm{~g})$ in cultivation trial-1, 2 and 3 , respectively. In rest two high yielding hybrid strains ( $\mathrm{VvH}-11$ and $\mathrm{VvH}-13)$, it varied from $16.25 \mathrm{~g}$ to $19.05 \mathrm{~g}$ in three trials. The cumulative mean fruiting body weight of three trials again showed, hybrid strain $\mathrm{VvH}-18$ with the heaviest fruiting bodies $(20.38 \mathrm{~g})$ as compared to two parents (16.77 and $18.00 \mathrm{~g}$ ).

The effect of growing room environment on fruiting body yield of the hybrid strains, one SSI and two parent strains was studied for only trial-2. On $1^{\text {st }}$ shelf (top, $5.5 \mathrm{ft}$. height from floor), the parent strain $\mathrm{P}-2$, followed by $\mathrm{P}-1$ and hybrid $\mathrm{VvH}-11$ gave highest fruiting body yield. On $2^{\text {nd }}$ shelf ( $4.0 \mathrm{ft}$. height from floor), hybrid strain $\mathrm{VvH}-11$ gave highest fruiting body yield, followed by parent strain $\mathrm{P}-1$, hybrid strain $\mathrm{VvH}-13$ and $\mathrm{VvH}-18$. On ${ }^{\text {rd }}$ shelf (2.5 ft. height from floor), hybrid strain $\mathrm{VvH}-11$ gave highest yield, followed by $\mathrm{VvH}-13$ and $\mathrm{VvH}-18$. On $4^{\text {th }}$ shelf $(1.0 \mathrm{ft}$. height from floor), hybrid strain $\mathrm{VvH}-13$ gave highest yield, followed by $\mathrm{VvH}$ 11 and $\mathrm{VvH}-18$. Hybrid strain $\mathrm{VvH}-13$ was recorded as consistent yielder across all heights, while hybrid strain $\mathrm{VvH}-11$ was superior performer in top three shelves. Hybrid strain $\mathrm{VvH}-18$ and parent strain $\mathrm{P}-1$ showed a gradient in yield from top to bottom shelves (Fig. 1). This proves that strain $\mathrm{VvH}-11$ and $\mathrm{VvH}-18$ are more suited for high temperature conditions prevailing on top shelves, while strain $\mathrm{VvH}-13$ can give fairly good yield under wide temperature, relative humidity and $\mathrm{CO}_{2}$ range. Such types of

Table 1 : Initial screening of newly developed hybrids and single spore isolates of Volvariella volvacea for fruiting body yield and related attributes

\begin{tabular}{llll}
\hline $\begin{array}{l}\text { Hybrid strains/single } \\
\text { spore isolates }\end{array}$ & $\begin{array}{l}\text { Time taken for first harvest } \\
\text { (days) }\end{array}$ & $\begin{array}{l}\text { Fruiting body yield } \mathbf{( k g ~ q} \mathbf{~}^{-1} \\
\text { dry substrate) }\end{array}$ & $\begin{array}{l}\text { Fruiting body weight } \\
\text { (g) }\end{array}$ \\
\hline VvS-11 & 12.63 & $10.41 \pm 1.19 \mathrm{a}-\mathrm{e}$ & $20 \pm 1.75 \mathrm{a}-\mathrm{e}$ \\
VvS-12 & 14.29 & $2.23 \pm 1.47 \mathrm{c}-\mathrm{e}$ & $16.76 \pm 4.35 \mathrm{~b}-\mathrm{f}$ \\
VvS-13 & 16.50 & $0.38 \pm 0.29 \mathrm{de}$ & $14.00 \pm 3.66 \mathrm{ef}$ \\
VvS-14 & 13.98 & $2.91 \pm 2.39 \mathrm{~b}-\mathrm{e}$ & $23.34 \pm 5.83 \mathrm{c}-\mathrm{f}$ \\
VvS-15 & 13.26 & $6.94 \pm 1.86 \mathrm{a}-\mathrm{e}$ & $11.27 \pm 1.75 \mathrm{a}-\mathrm{f}$ \\
VvS-16 & 12.77 & $10.44 \pm 3.51 \mathrm{a}-\mathrm{e}$ & $14.9 \pm 1.49 \mathrm{a}-\mathrm{f}$ \\
VvS-17 & 18.09 & $0.59 \pm 0.59 \mathrm{de}$ & $17.75 \pm 3.55 \mathrm{ef}$ \\
VvS-18 & 17.51 & $2.01 \pm 1.05 \mathrm{c}-\mathrm{e}$ & $8.32 \pm 2.07 \mathrm{~d}-\mathrm{f}$ \\
VvH-11 & 11.82 & $13.08 \pm 2.7 \mathrm{a}-\mathrm{c}$ & $23.96 \pm 2.83 \mathrm{a}-\mathrm{c}$ \\
VvH-13 & 12.09 & $11.35 \pm 1.82 \mathrm{a}-\mathrm{d}$ & $19.81 \pm 1.02 \mathrm{a}-\mathrm{e}$ \\
VvH-16 & 12.47 & $17.28 \pm 3.69 \mathrm{a}$ & $27.73 \pm 2.64 \mathrm{a}$ \\
VvH-17 & 13.11 & $14.05 \pm 3.98 \mathrm{ab}$ & $18.01 \pm 2.23 \mathrm{a}-\mathrm{e}$ \\
VvH-18 & 12.34 & $12.75 \pm 1.77 \mathrm{a}-\mathrm{c}$ & $26.35 \pm 3.6 \mathrm{ab}$ \\
VvH-19 & 13.59 & $7.42 \pm 1.51 \mathrm{a}-\mathrm{e}$ & $17.81 \pm 1.81 \mathrm{a}-\mathrm{e}$ \\
VvH-20 & 14.16 & $7.7 \pm 1.6 \mathrm{a}-\mathrm{e}$ & $19.75 \pm 1.22 \mathrm{a}-\mathrm{e}$ \\
VvH-21 & 16.86 & $2.88 \pm 2.68 \mathrm{~b}-\mathrm{e}$ & $18.59 \pm 5.3 \mathrm{~d}-\mathrm{f}$ \\
VvH-22 & No fruiting & Nofruiting e & No fruiting \\
VvH-23 & 13.13 & $6.24 \pm 2.28 \mathrm{a}-\mathrm{e}$ & $16.94 \pm 2.27 \mathrm{a}-\mathrm{e}$ \\
P-1 & 12.28 & $9.36 \pm 2.78 \mathrm{a}-\mathrm{e}$ & $16.68 \pm 2.83 \mathrm{a}-\mathrm{e}$ \\
P-2 & 13.34 & $9.64 \pm 1.03 \mathrm{a}-\mathrm{e}$ & $22.14 \pm 6.29 \mathrm{a}-\mathrm{d}$ \\
\hline
\end{tabular}

Values are mean \pm S.E.; Means with same letter are not significantly different 
Table 2 : Fruiting body yield performance of selected hybrids and single spore isolates of Volvariella volvacea during three trials performed under different environments

\begin{tabular}{|c|c|c|c|c|c|c|c|c|}
\hline \multirow[t]{2}{*}{ Hybrids/SSIs } & \multicolumn{4}{|c|}{ Fruiting body yield ( $\mathrm{kg} \mathrm{q}^{-1}$ dry substrate) } & \multicolumn{4}{|c|}{ Mean fruiting body weight (g) } \\
\hline & Trial-1 & Trial-2 & Trial-3 & Mean & Trial-1 & Trial-2 & Trial-3 & Mean \\
\hline VvH-11 & $21.79 a b$ & $29.99 a$ & $33.18 \mathrm{a}$ & 28.32 & $16.25 a b$ & $17.54 \mathrm{ab}$ & $19.02 a$ & 17.60 \\
\hline VvH-13 & $23.25 a b$ & $25.76 a$ & $29.62 a b$ & 26.21 & $19.05 a b$ & $17.80 \mathrm{ab}$ & $17.53 a$ & 18.13 \\
\hline VvH-16 & $15.41 b$ & NotDone & $2.62 d$ & 9.02 & $20.66 b$ & NotDone & $7.89 \mathrm{c}$ & 15.07 \\
\hline VvH-17 & $18.84 a b$ & $9.93 b$ & $13.99 c$ & 14.25 & 18.39ab & $14.46 b$ & $11.03 b c$ & 14.63 \\
\hline VvH-18 & $27.23 a$ & $25.74 a$ & $24.35 b$ & 25.77 & $21.05 a$ & $20.11 a$ & $19.99 a$ & 20.38 \\
\hline VvS-11 & 21.96ab & $23.45 a$ & $23.52 b$ & 22.98 & 15.85ab & $14.90 \mathrm{~b}$ & $17.52 \mathrm{a}$ & 16.09 \\
\hline VvS-16 & $1.30 c$ & NotDone & NotDone & 1.30 & $21.75 c$ & NotDone & NotDone & 18.89 \\
\hline P-1 & 19.18ab & $27.09 a$ & $25.10 b$ & 23.79 & $16.78 \mathrm{ab}$ & $16.03 b$ & 15.83ab & 16.77 \\
\hline P-2 & 19.39ab & $25.91 a$ & $15.26 c$ & 20.19 & 18.87ab & 17.69ab & $17.58 \mathrm{a}$ & 18.00 \\
\hline
\end{tabular}

Means with same letter are not significantly different

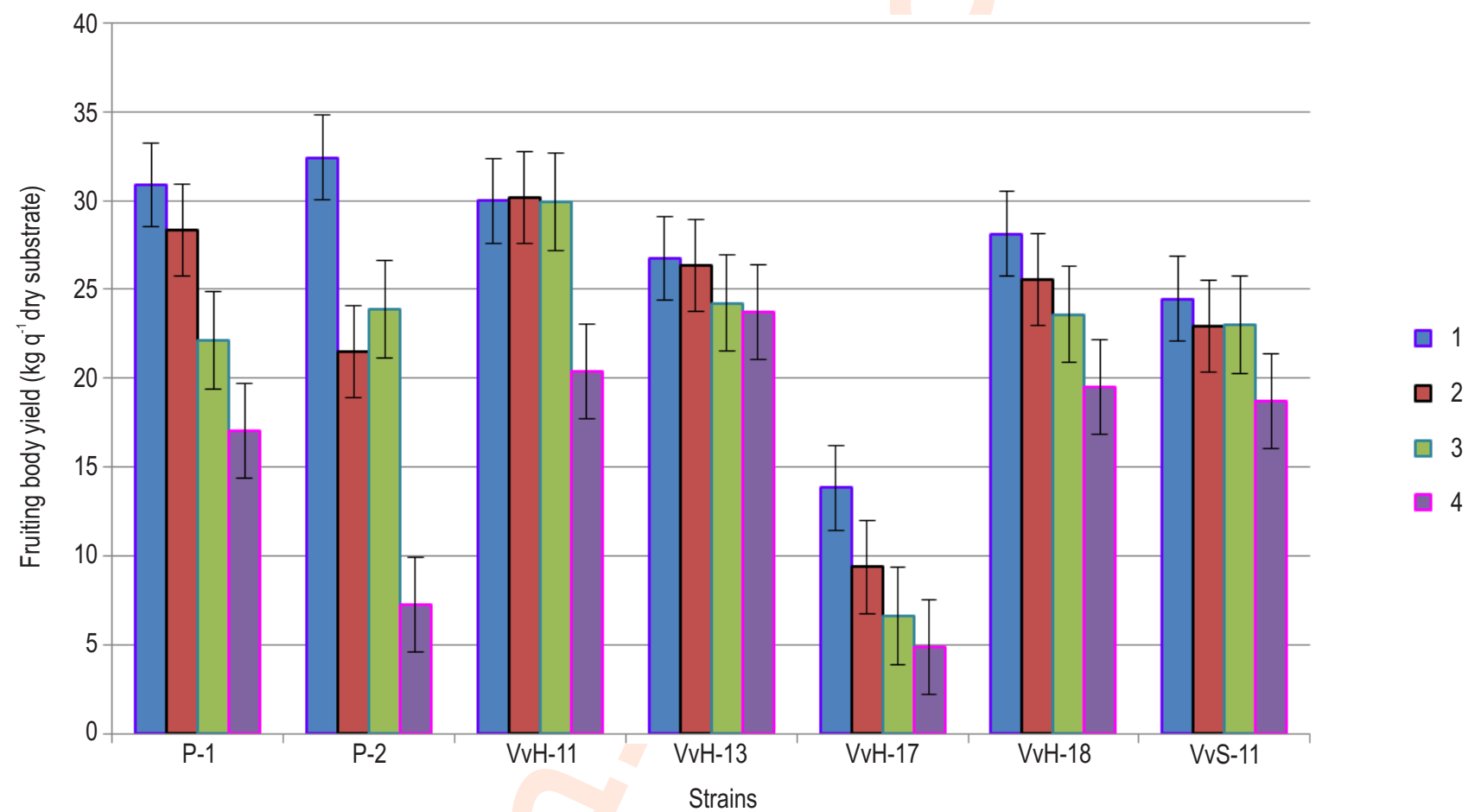

Fig. 1 : Yielding pattern in different hybrid strains, SSI and parent strains on different height levels in growing room.

studies are rare and this may be of first type. In one such study, the fruiting body yields in $V$. volvacea strains were studied across different cropping periods (Sharma et al., 2019). In respect to fruiting body weight, the strains did not show any set trend with changes in cropping heights (shelves). Widest gap was recorded in parent strain $\mathrm{P}-1$, which exhibited heaviest fruiting bodies on $4^{\text {th }}$ shelf (lowest shelf). Conversely, lightest weighing fruiting bodies were recorded in hybrid strain $\mathrm{VvH}-11, \mathrm{VvH}-13$ and $\mathrm{VvH}-18$ on $4^{\text {th }}$ shelf. Effect of cropping height was least in parent strain P-2 and hybrid strain $\mathrm{VvH}-13$, where fruiting body weight ranged between 16 to $20 \mathrm{~g}$ (Fig. 2). Such type of information is meager in literature.
Till recent past, $V$. volvacae was considered as a difficult mushroom to generate hybrids due to ambiguity in its mating system and absence of stable biomarkers for authentication of the off springs (Chang and Yau, 1971). However, few earlier and latest studies have reported the phenotypic variations in mycelial growth characteristics of the progenies of $V$. volvacea, supporting existence of large variability which possibly may have arised via natural cross breeding system (Chang and Yau, 1971; Chang, 1978; Ahlawat et al., 2008). Similarly, limited studies have also supported the occurrence of natural combinations leading to heterokaryocity in V. volvacea (Ahlawat and Billette, 2011; Chiu et 


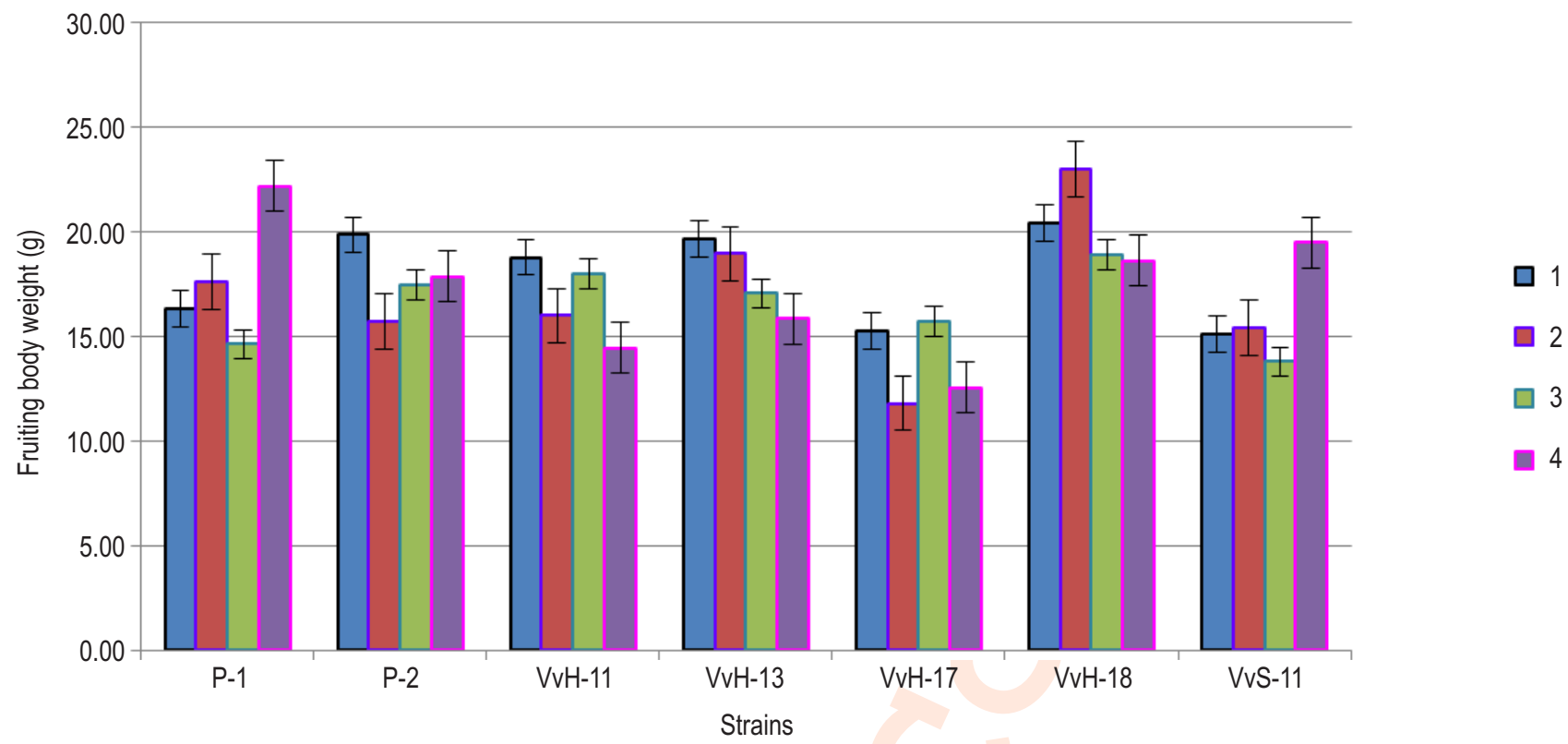

Fig. 2 : Fruiting body weight in different hybrid strains, SSI and parent strains as affected by different height levels in growing room.

Table 3: Proximate composition of fruiting bodies from different hybrids and single spore isolates of Volvariella volvacea

\begin{tabular}{|c|c|c|c|c|c|c|c|c|c|c|}
\hline \multirow{2}{*}{$\begin{array}{l}\text { Hybrids/ } \\
\text { SSls }\end{array}$} & \multicolumn{10}{|c|}{ Proximate composition } \\
\hline & $\begin{array}{l}\text { Protein } \\
(\%)\end{array}$ & $\begin{array}{l}\text { Fat } \\
(\%)\end{array}$ & $\begin{array}{l}\text { Crude } \\
\text { Fiber }(\%)\end{array}$ & $\begin{array}{l}\text { Ash } \\
(\%)\end{array}$ & $\begin{array}{l}\text { Potassium } \\
(\%)\end{array}$ & $\begin{array}{l}\text { Manganese } \\
(\mathrm{ppm})\end{array}$ & $\begin{array}{l}\text { Zinc } \\
\text { (ppm) }\end{array}$ & $\begin{array}{l}\text { Selenium } \\
\text { (ppm) }\end{array}$ & $\begin{array}{l}\text { Vitamin C } \\
\left(\mathrm{mg} 100 \mathrm{~g}^{-1}\right)\end{array}$ & $\begin{array}{l}\text { Vitamin D } \\
\left(\mu g 100 \mathrm{~g}^{-1}\right)\end{array}$ \\
\hline VvH-11 & 31.23 & 1.86 & 2.07 & 10.95 & 3.7 & 13.48 & 56.76 & 0.18 & 40.67 & 1098 \\
\hline VvH-13 & 32.78 & 1.55 & 2.00 & 9.32 & 3.60 & 14.46 & 60.82 & 0.20 & 52.35 & 1434.7 \\
\hline VvH-16 & 42.57 & 2.02 & 1.63 & 10.32 & 3.9 & 22.64 & 72.89 & 0.31 & 46.76 & 952.7 \\
\hline VvH-17 & 29.22 & 1.90 & 1.40 & 8.58 & 3.5 & 14.45 & 56.51 & 0.24 & 44.83 & 967.3 \\
\hline VvH-18 & 36.45 & 1.54 & 1.74 & 9.34 & 3.7 & 22.46 & 67.10 & 0.26 & 43.13 & 607.4 \\
\hline VvS-11 & 45.46 & 1.93 & 1.58 & 10.34 & 3.4 & 18.87 & 83.63 & 0.27 & 44.47 & 708.1 \\
\hline$P-1$ & 39.78 & 2.54 & 1.09 & 10.53 & 4.00 & 16.27 & 84.61 & 0.23 & 42.33 & 1150.8 \\
\hline P-2 & 30.1 & 2.59 & 1.26 & 10.08 & 4.00 & 11.53 & 59.58 & 0.26 & 42.97 & 926.7 \\
\hline
\end{tabular}

al., 1995). The findings of Xiong et al. (2014), supporting existence of secondary homothallism in $V$. volvacea raised the possibility of developing hybrid strains by making crosses between the compatible homokaryons. The present work of isolation and utilization of two types of SSIs (slow growing with 'atypical' and fast growing with 'typical' mycelial growth) in selection of high yielding SSIs and development of hybrid strains is in line with the work of Chang et al. (1981), where four morphologically distinct types of SSIs were reported. Alike $A$. bisporus, where non-fertile SSIs are used in hybrid strain development; the slow growing SSIs (possibly homokaryons) were used in present study for developing hybrid strains, as was also done earlier by Xiong et al. (2014). Another possibility is generation of a heterokaryon via anastomosis between a homokaryon and a heterokaryon, following Buller phenomenon as in case of A. bisporus (Buller, 1931). In this case, the hybrid receives one nucleus of the homokaryon and one of the two nuclei of the heterokaryon (which must be sexually compatible with the nucleus of the homokaryon).

The selection of high yielding SSIs in present study is in line with the earlier study of Ahlawat et al. (2017), however, stability in yield is a major issue. Alternatively, selection of strains or development of hybrid strains for higher fruiting body yield has been attempted by several researchers on $V$. volvacea (Garcha et al., 1986; Ahlawat et al., 2011; Liu et al., 2011; Xiong et al., 2014; Ahlawat et al., 2017) with variable success. In present study, the fast growing SSIs and the hybrid strains showing higher downward mycelial growth on paddy straw compared to parent strains were evaluated at two stages for fruiting body yield and nutritional quality. At large scale evaluation, three trials were conducted using completely indoor system of cultivation. Such a 
systematic system of screening and evaluation in this mushroom has not been reported much. In few cases, attempts have also been made to generate new strains either through hybridization, mutagenesis and protoplast fusion (Xiong et al., 2014; Liu et al., 2011; He et al., 2018). Development of hybrid strains by crossing the compatible SSIs is restricted to only very few studies (Xiong et al., 2014; Ahlawat et al., 2017).

The strains generated through mutagenesis have exhibited $46.1 \%$ and $40.5 \%$ higher biological efficiency compared with control strain along with longer shelf-life of fruiting bodies at $16^{\circ} \mathrm{C}$ (Liu et al., 2011). Similarly, three hybrids out of 58 generated through cross-breeding between 72 compatible pairs, have been reported as high quality hybrids (Xiong et al., 2014). Earlier, Ahlawat et al. (2017) have reported three high yielding hybrids with superior shelf life of the fruiting bodies by adopting the same approach. As per one recent study, cold tolerant hybrids have been developed by inter-species protoplast fusion between $V$. volvacea and Pleurotus eryngii, and the resultant hybrids had higher biological efficiency and shelf-life on storage at $16^{\circ} \mathrm{C}(\mathrm{He}$ et al., 2018). Present study along with earlier findings has validated the possibilities of generating quality hybrids in $V$. volvacea using slow growing compatible homokaryons.

The protein content in high yielding hybrid strains ranged between 31.23 to $36.45 \%$ with highest in $\mathrm{VvH}-18$. Fat content was lower in all high yielding hybrid strains (1.54 to $1.86 \%$ ) compared to parent strains (2.54 and $2.59 \%)$. Crude fiber was higher (1.74 to $2.07 \%$ ) in all high yielding hybrid strains compared to parents (1.09 and $1.26 \%)$. Ash content was highest in high yielding strain $\mathrm{VvH}-11$ (10.95\%). Amongst minerals and vitamins, higher level of manganese, selenium and vitamin $\mathrm{C}$ was in hybrid strain $\mathrm{VvH}-18$, while highest level of vitamin $\mathrm{C}$ and vitamin $\mathrm{D}$ was in hybrid strain $\mathrm{VvH}-13$ (Table 3). In present study, the hybrid strains have been found to differ in nutritional attributes of the fruiting bodies. There are not many reports of this type found in literature and in one earlier study, the hybrid strains have been reported to show variations in nutritional parameters of the fruiting bodies (Ahlawat et al., 2017). As in earlier study, the higher yielding strains have also been found to have higher mean fruiting body weight.

The study proves the possibility of developing hybrid strains in $V$. volvacea using conventional cross breading technique between possibly non-fertile homokaryons just like $A$. bisporus. The high yielding hybrid strains were also superior in key nutritional components and were able to perform equally good under varied environmental conditions of temperature, relative humidity and $\mathrm{CO}_{2}$ level, inside the cropping room.

\section{Acknowledgment}

The authors thank Science and Engineering Research Board, Ministry of Science and Technology, Govt. of India, New Delhi for financing the study.

\section{References}

A.O.A.C.: Official Methods of Analysis of AOAC International, $17^{\text {th }}$ Edn., $1^{\text {st }}$ revision, Gaithersburg, MD, USA, Association of Official Analytical Chemists (2002).

A.O.A.C.: Official Methods of Analysis of AOAC International, $18^{\text {th }}$ Edn., $2^{\text {nd }}$ revision, Gaithersburg, MD, USA, Association of Official Analytical Chemists (2007).

A.O.A.C.: Official Methods of Analysis of AOAC International, $19^{\text {th }}$ Edn., Gaithersburg, MD, USA, Association of Official Analytical Chemists (2012).

Ahlawat, O.P., P. Gupta, S. Kamal and B.L. Dhar: Development of molecular and biochemical markers for selecting a potential high yielding strain of paddy straw mushroom (Volvariella volvacea). J. Plant Biochem. Biotechnol., 17, 57-63 (2008).

Ahlawat, O.P. and C. Billette: Positioning of introns in different laccase genes, a relevant tool for solving phylogenetic position ambiguity of Volvariella volvacea laccase genes. In: Proceedings of $7^{\text {th }}$ International Conference on Mushroom Biology and Mushroom Products (Eds.: J.M. Savoie, M. Foulongne-Oriol, M. Largeteau and G. Barroso) WSMBMP and INRA, Bordeaux, France, pp. 100112 (2011).

Ahlawat, O.P., H. Kaur and B. Arora: Development and evaluation of hybrids and single spore isolates of Volvariella volvacea for fruit body yield, nutritional profile and shelf life. Sydowia, 69, 135-145 (2017).

Ahlawat, O.P., R. Singh and R.D. Rai: Influence of composted substrates on yield and nutritional attributes of culinary-medicinal paddy straw mushroom, Volvariella volvacea (Bull.: Fr.) Singer (Agaricomycetideae). Int. J. Med. Mushrooms, 11, 429-438 (2009).

Ahlawat, O.P., R. Singh and S. Kumar: Evaluation of Volvariella volvacea strains for yield and diseases/insect-pests resistance using composted substrate of paddy straw and cotton mill wastes. Indian J. Microbiol., 51, 200-205 (2011).

Bao, D.B., M. Gong, H.J. Zheng, M.J. Chen, L. Zhang, H. Wang, J.P. Jiang, L. Wu, Y.Q. Zhu, G. Zhu, Y. Zhou, C.H. Li, S.Y. Wang, Y. Zhao, G.P. Zhao and Q. Tan: Sequencing and comparative analysis of the straw mushroom (Volvariella volvacea) genome. PLOS ONE, 8, e58294 (2013).

Buller, A.H.R.: Researches on Fungi. Vol. IV. Longmans, Green and Co., London, United Kingdom (1931).

Chang S.T., P.G. Miles and C.C. Wai: A study of monosporous isolates of Volvariella volvacea. Mushroom Sci., 11, 603-621 (1981).

Chang, S.T. and P.G. Miles: Cultivation, nutritional value, medicinal effect and environmental impact. CRC Press LLC, Boca Raton (2004).

Chang S.T.: Volvariella volvacea. In: The biology and cultivation of edible fungi (Eds.: S.T. Chang and W.A. Hayes). Academic Press, New York, pp. 573-605 (1978).

Chang, S.T. and C.K. Yau: Volvariella volvacea and its life history. Am. J. Bot., 58, 552-561 (1971).

Chiu, S.W., M.J. Chen and S.T. Chang: Differentiating homothallic Volvariella mushrooms by RFLPs and AP-PCR. Mycol. Res., 99, 333-336 (1995).

Chiu, S.W.: Evidence for a haploid life-cycle in Volvariella volvacea from micro spectrophotometric measurements and observations of nuclear behavior. Mycol. Res., 97, 1481-1485 (1993).

Garcha, H.S., H.S. Sodhi, R.P. Phutela and P.K. Khanna: Evaluating strains of paddy straw mushroom (Volvariella spp.) in India. In: 
Proceedings of International Symposium on Scientific and Technical Aspects of Cultivating Edible Fungi. Elsevier Science Publishers, B.V. Amsterdam, pp. 533-544 (1986).

He, B.L., L.R. You, Z.W. Ye, L.Q. Guo, J.F. Lin, T. Wei and Q.W. Zheng: Construction of novel cold-tolerant strains of Volvariella volvacea through protoplast fusion between Volvariella volvacea and Pleurotus eryngii. Sci. Hortic., 230, 161-168 (2018).

Liu, Z., K. Zhang, J.F. Lin and L.Q. Guo: Breeding cold tolerance strain by chemical mutagenesis in Volvariella volvacea. Sci. Hortic., 130, 18-24 (2011).

Mehta, K.B.: Validity of mycelial growth as selection criterion for yield in Agaricus bisporus. Indian J. Mushrooms, 14, 16-19(1988).

Quimio, T.H.: Indoor cultivation of the straw mushroom Volvariella volvacea. Mushroom Res., 2, 87-90 (1993).

Sharma, V.P., A. Kumar, A. Barh, S. Kamal and S. Kumar: Adaptability and trait stability analysis in Volvariella volvacea (paddy straw mushroom). Int. J. Curr. Microbiol. App. Sci., 8, 1462-1471(2019).
She, Q.B., T.B. Ng and W.K. Liu: A novel lectin with potent immunomodulatory activity isolated from fruiting bodies and cultivated mycelia of the edible mushroom Volvariella volvacea. Biochem. Bioph. Res. Commun., 247, 106-111 (1998).

STAR, version 2.0.1. Biometrics and breeding informatics, PBGB Division, International Rice Research Institute, Los Baños, Laguna, Philippines (2014).

Thakur, M.P.: Present status and future prospects of tropical mushroom cultivation in India: A review. Indian Phytopath., 67, 113-125 (2014).

Tukey, J.: Comparing individual means in the analysis of variance. Biometrics, 5, 99-114 (1949).

Xiong, D., H. Wang, M. Chen, C. Xue, Z. Li, Y. Bian and D. Bao: Application of mating type genes in molecular marker-assisted breeding of the edible straw mushroom Volvariella volvacea. Sci. Hortic., 180, 59-62 (2014). 